\title{
Synthesis and characterization of the $\mathrm{NiFe}_{2} \mathrm{O}_{4} @ \mathrm{TEOS}-\mathrm{TPS} @ \mathrm{Ag}$ nanocomposite and investigation of its antibacterial activity
}

\author{
Authors: Ali R. Allafchian*a, S.A.H. Jalali ${ }^{\text {b,c }}$, R. Amiri ${ }^{\text {a }}$, Sh. Shahabadi ${ }^{\mathrm{a}}$
}

\author{
Addresses: \\ ${ }^{a}$ Nanotechnology and Advanced Materials Institute, Isfahan University of Technology, Isfahan \\ 84156-83111, Iran \\ ${ }^{\mathrm{b}}$ Department of Natural Resources, Isfahan University of Technology, Isfahan 84156-83111, \\ Iran \\ ${ }^{\mathrm{c}}$ Institute of Biotechnology and Bioengineering, Isfahan University of Technology, Isfahan \\ 84156-83111, Iran \\ Email addresses:
}

S.A.H. Jalali: ahjalali2002@gmail.com

Razieh Amiri: razieh.amiri@gmail.com

Shirin Shahabadi: shirinshahabadi@rocketmail.com

*Corresponding author:

Tel.: +98 313 3912282; Fax: +983133919014

E-mail: Allafchian@cc.iut.ac.ir. 


\begin{abstract}
In this study, the $\mathrm{NiFe}_{2} \mathrm{O}_{4}$ was embedded in (3-mercaptopropyl) trimethoxysilane (TPS) and tetraethyl orthosilicate (TEOS) using the sol-gel method. These compounds were used as the support of $\mathrm{Ag}$ nanoparticles (Ag NPs). The $\mathrm{NiFe}_{2} \mathrm{O}_{4} @ \mathrm{TEOS}-\mathrm{TPS} @ \mathrm{Ag}$ nanocomposites were obtained with the development of bonding between the silver atoms of Ag NPs and the sulfur atoms of TPS molecule. Field emission scanning electron microscopy (FE-SEM), transmission electron microscopy (TEM), X-ray diffraction (XRD) and Fourier transform infrared spectroscopy (FT-IR) were used for the characterization of the Ag nanocomposites. Also, the magnetic properties of these nanocomposites were studied by using a vibrating sample magnetometer (VSM) technique. The disk diffusion, minimum inhibition concentration (MIC) and minimum bactericidal concentrations (MBC) tests were used for the investigation of the antibacterial effect of this nanocomposite against bacterial strains. The synthesized nanocomposite presented high reusability and good antibacterial activity against gram-positive and gram-negative bacteria. Remarkably, this nanocomposite could be easily removed from the disinfected media by magnetic decantation.
\end{abstract}

Keywords: Silver nanocomposite; Antibacterial activity; So-gel; Recyclability 


\section{Introduction}

Nanotechnology science has been quickly growing in the last decade. More than 1300 referenced products are dispersed in various groups such as solar energy absorption, chemical catalysis, health, electronics, toys, etc. [1-4]. Because of the antimicrobial properties of silver nanoparticles (Ag NPs), these nanoparticles are classified among consumer products with the most abundant nanomaterial and hence, they can be used as alternative disinfectant agents.

One of the most important problems in using of Ag NPs is the release of Ag ions in the environment and the resulting disruption in the ecosystem. The released $\mathrm{Ag}$ ions values in solution is relative inversely to the size of $\operatorname{Ag}$ NPs $[5,6]$ and also surface coating $[7,8]$. Therefore, different studies have been carried out to address this issue using various stabilizing agents with large size, such as surfactants, dodecanethiol, sodium citrate, aminosilanes and polymers, to ensure the stable dispersion of Ag NPs in liquid solutions [9]. To achieve the favorable stabilizing agents, some core/shell nanostructures were designed. The universal spinel ferrite of $\mathrm{Fe}_{3} \mathrm{O}_{4}, \mathrm{CoFe}_{2} \mathrm{O}_{4}, \mathrm{MnFe}_{2} \mathrm{O}_{4}$ and $\mathrm{NiFe}_{2} \mathrm{O}_{4}$ are used as the core of nanostructure [10-14]. Because of the corrosion rate decreases in nano alloy ferrites $\left(\mathrm{XFe}_{2} \mathrm{O}_{4}\right)$, therefore, they can be more suitable than $\mathrm{Fe}_{3} \mathrm{O}_{4}$ for industrial application i.e. economically and efficiently $[15,16]$. Some polymers such as casein, dextrin, polyvinylpyrrolidone (PVP) [5, 17], polyethylene (PE) [18], poly(vinylchloride) (PVC) [19] and poly-triallylamine [20] have been examined as the shell of them. This procedure has such advantages as the convenient immobilization and separation of them through the magnetite field from media $[21,22]$.

Also, reusability is one of the greatest challenges in employing nanoparticle materials for antimicrobial and practical applications. Confidently, by decreasing Ag ions release from Ag NPs in solution, the recyclability or reusability of them can be increased. The increment in reusability without the loss of antibacterial activity suggests that nanoparticles have good 
stability and therefore, they can be used as a recyclable antibacterial. Some studies have been done on the recyclability of various nanomagnetic particles [21, 23-26]. Ag nanoparticles, as a kind of heterogeneous, recyclable and moisture stable catalyst, have been used for the synthesis of $\beta$-enaminones and $\beta$-enamino esters [27]. Zhang and Altangerel have shown that the $\mathrm{Ag} / \mathrm{Fe}_{3} \mathrm{O}_{4}$ nanocomposites not only have a strong antibacterial activity, but also a magnetically recyclable property and therefore, they can be used as novel reusable antibacterial materials [10, 28]. Also, $\mathrm{Ag}-\mathrm{CuFe}_{2} \mathrm{O}_{4}$ magnetic material, as a recyclable nanocomposite, exhibits excellent antibacterial efficiency against four different bacteria [29]. The disinfection activity of $\mathrm{Ag} / \mathrm{TiO}_{2}$ nanofiber membrane has no obvious decrease after the continuous five times recycle [30].

There is a serious risk for drinking water consumers before its treatment as the load of protozoa, fungi, bacteria and viruses should be decreased [31]. Therefore, disinfection is essential to regulator microbial health risks and it has usually been obtained by chlorination or ultraviolet irradiation. Recent studies have indicated that after water disinfection treatment, there are some residual pathogens such as Pseudomonas aeruginosa and $\beta$-Proteobacteria that are resistant to chlorination or UV disinfection. Hence, these two techniques are not adequate for the complete removal of pathogens from water $[32,33]$.

Accordingly, with selection of $\mathrm{NiFe}_{2} \mathrm{O}_{4}$ as nanocomposite core, tetraethyl orthosilicate (TEOS) and (3-mercaptopropyl) trimethoxysilane (TPS) was reacted by using the sol-gel method for TEOS-TPS making with large size that used as a shell of core. Therefore, $\mathrm{NiFe}_{2} \mathrm{O}_{4}$ was selected as core of nanocomposite. Then, immobilization of Ag NPs on the $\mathrm{NiFe}_{2} \mathrm{O}_{4} @$ TEOS-TPS surface creates $\mathrm{NiFe}_{2} \mathrm{O}_{4} @ \mathrm{TEOS}-\mathrm{TPS} @ \mathrm{Ag}$ nanocomposite. Some spectroscopic techniques such as field emission scanning of electron microscopy (FE-SEM), transmission electron microscopy (TEM), Fourier transform infrared spectroscopy (FT-IR) and $\mathrm{X}$-ray diffraction (XRD) were applied for the characterization of the as-prepared 
nanocomposites. Vibrating sample magnetometer (VSM) method was used for the evaluation of nanocomposite magnetic properties. The antibacterial activity of this nanocomposite against bacterial strains was studied by the disk diffusion, minimum inhibition concentration (MIC) and minimum bactericidal concentration (MBC) methods. These nanocomposites showed an appropriate antibacterial activity against gram-positive and gram-negative bacteria and high recyclability. In addition, the separation of this silver nanocomposite was simply carried out by some magnetic decantation that was essential after water treatment.

\section{Experimental details}

\subsection{Materials and methods}

The $\mathrm{NaOH}, \mathrm{Fe}\left(\mathrm{NO}_{3}\right)_{3}, \mathrm{Na}\left(\mathrm{BH}_{4}\right), \mathrm{Ni}\left(\mathrm{NO}_{3}\right)_{2}$ and $\mathrm{Ag}\left(\mathrm{NO}_{3}\right)$, TEOS and TPS were purchased from Merck Co. (Germany). Deionized and doubly distilled water were used as a solvent in this research. The FT-IR spectrum was achieved using a FT-IR Jasco Japan spectrophotometer. A Philips X-ray diffractometer by using $\mathrm{Cu} \mathrm{K}_{\alpha}$ radiation $\left(\lambda^{1} \frac{1}{4} 0.154 \mathrm{~nm}\right)$ was applied to XRD profiles of the produced samples. The Hitachi Japan S4160 field emission scanning electron microscope was used for FE-SEM images of the nanocomposites. By utilizing of a Philips CM10-HT 100KV microscope, the TEM image scanned for the morphology and size of the as-prepared nanoparticles investigation. The magnetic properties of the as prepared composites were studied by using a vibrating sample magnetometer (VSM) from Meghnatis Daghigh Kavir Company (Iran). Single-point Brunauer-Emmett-Teller (BET; NanoSord, Iran) technique was applied for calculating the surface area of the synthesized nanomaterials.

\subsection{Synthesis of $\mathrm{NiFe}_{2} \mathrm{O}_{4}$}


Nickel ferrite nanoparticles were prepared by a citrate gel method using nickel (II) and iron (III) nitrates with a known amount of citrate [34]. At First, a solution containing $\mathrm{Fe}\left(\mathrm{NO}_{3}\right)_{3} \cdot 9 \mathrm{H}_{2} \mathrm{O}$ and $\mathrm{Ni}\left(\mathrm{NO}_{3}\right) \cdot 6 \mathrm{H}_{2} \mathrm{O}$ was prepared, with Fe:Ni molar ratio being kept at 2:1. Then, $0.02 \mathrm{~mol}$ of citric acid was added to the solution and by using the hydroxide ammonium solution, the $\mathrm{pH}$ value was adjusted to 9.0. This reaction was completed by stirring the mixture at $30{ }^{\circ} \mathrm{C}$ for $2 \mathrm{~h}$. The produced mixture was dried in an oven at $100{ }^{\circ} \mathrm{C}$ for $24 \mathrm{~h}$. The prepared substance was calcinated at $600{ }^{\circ} \mathrm{C}$ for $2 \mathrm{~h}$ in argon atmosphere.

\subsection{Preparation of TEOS-TPS}

For preparing the TPS and TEOS solution, the sol-gel method was employed. Initially, the solution of $51.3 \%$ weight of TEOS/absolute ethanol was prepared and stirred to complete mixing. Then, TPS was added to a TEOS/ethanol solution in which the weight percent of TEOS was equal to 5\%. Afterwards, a solution of hydrochloric acid $(\mathrm{pH}: 1)$ and absolute ethanol, with relative 2/100, was added to the last solution. Magnetic stirring of the hydrolyzed solution was done for $3 \mathrm{~h}$ and followed by leaving the solution at room temperature for 24 hours.

\subsection{Preparation of Ag NPs}

The synthesis of silver nanoparticles, which is well known, has been developed by using various methods [35-38]. In this study, silver nanoparticles were synthesized by following a procedure described by Varaprasad [36]. In the typical synthesis of silver nanoparticles, a solution $\mathrm{AgNO}_{3}$ was added to sodium borohydrate in which the $\mathrm{Na}: \mathrm{Ag}$ molar ratio reached to 2:1. After $2 \mathrm{~h}$, the synthesized Ag NPs was washed with distilled water several times to remove any excess protecting agent. The final product was dried in an oven at $50{ }^{\circ} \mathrm{C}$ for $2 \mathrm{~h}$. 


\subsection{Synthesis of $\mathrm{NiFe}_{2} \mathrm{O}_{4} @ \mathrm{TEOS}-\mathrm{TPS}$ and $\mathrm{NiFe}_{2} \mathrm{O}_{4} @ \mathrm{TEOS}-\mathrm{TPS} @ \mathrm{Ag}$ nanocomposites}

At first, $4.3 \mathrm{mmoL}$ of $\mathrm{NiFe}_{2} \mathrm{O}_{4}$ was added to $1 \mathrm{~mL}$ of TEOS-TPS solution. After that, the mixture was further sonicated for 10 min. Finally, the collected $\mathrm{NiFe}_{2} \mathrm{O}_{4} @$ TEOS-TPS composite was dried in an oven at $60^{\circ} \mathrm{C}$ for $6 \mathrm{~h}$.

The $\mathrm{NiFe}_{2} \mathrm{O}_{4} @$ TEOS-TPS@Ag nanocomposite was prepared. In this nanocomposite, $1.0 \mathrm{~g}$ of $\mathrm{NiFe}_{2} \mathrm{O}_{4} @$ TEOS-TPS has been dispersed by ultrasonic in $\mathrm{AgNO}_{3}$ aqueous solution ( $2 \mathrm{mmoL}$ ) for $5 \mathrm{~min}$. After this step, a solution of hydrazine, as the reducing agent, was introduced into the reaction vessel. After $1 \mathrm{~h}$, the prepared $\mathrm{NiFe}_{2} \mathrm{O}_{4} @$ TEOS-TPS@Ag nanocomposite was collected by the magnet and washed tree times with water and dried in an oven at $60{ }^{\circ} \mathrm{C}$ for $6 \mathrm{~h}$.

\subsection{Antibacterial tests of the nanocomposite}

The Kirby-Bauer disk diffusion procedure, as a standard method, was used to assess the antibacterial activity of the nanocomposites [39]. In the previous study, we have explained this method in details [14]. Briefly, the Bacillus cereus (ATCC 14579) and Staphylococcus aureus (ATCC 29213) bacteria, for gram positive assessment, and Salmonella typhimurium (ATCC 14028) and Escherichia coli (ATCC 35218) bacteria, for gram negative assessment, were chosen and suspended in phosphate buffer saline (PBS). The bacterial suspensions turbidity was adjusted to the $0.5 \mathrm{McFarland}$ standard and sterile swabs were dipped into the inoculum tubes. The $\mathrm{Ag} \mathrm{NPs}, \mathrm{NiFe}_{2} \mathrm{O}_{4}, \mathrm{NiFe}_{2} \mathrm{O}_{4} @$ TEOS-TPS and $\mathrm{NiFe}_{2} \mathrm{O}_{4} @ \mathrm{TEOS}-$ TPS@Ag suspensions were prepared by separately dissolving $0.1 \mathrm{mg}$ of the mentioned nanoparticle in $1 \mathrm{~mL}$ distillated water. After the sonication of them for $10 \mathrm{~min}$, the standard discs of $\mathrm{Ag} \mathrm{NPs}, \mathrm{NiFe}_{2} \mathrm{O}_{4}, \mathrm{NiFe}_{2} \mathrm{O}_{4} @ \mathrm{TEOS}-\mathrm{TPS}$ and $\mathrm{NiFe}_{2} \mathrm{O}_{4} @ \mathrm{TEOS}-\mathrm{TPS} @ \mathrm{Ag}$ were separately prepared, and distillated water was used as a negative control. At the end, the discs were 
utilized to assess the antibacterial activity against four different bacterial strains on MuellerHinton agar (Merck, Germany) plates. Impregnated disks were located on the surface of the agar using sterile forceps. Then, these plates were incubated at $37{ }^{\circ} \mathrm{C}$ for $24 \mathrm{~h}$ to check the antibacterial activity. The antibacterial activities assays were done in triplicate (the zone of inhibition) and measured in millimeter unit.

\subsection{Minimum -inhibitory and-bactericidal concentrations (MIC and MBC)}

The MIC is the lowest concentration of antimicrobial agents inhibiting $99 \%$ growth of the microorganisms. As explained in the previous section, by putting subculturing bacteria into the sterile nutrient, broth bacterial inocula were provided at $37^{\circ} \mathrm{C}$ for $24 \mathrm{~h}$. The solutions of bacteria were approximately diluted to $10^{6} \mathrm{CFU}$ (colony forming units) $/ \mathrm{mL}$. The solutions of $\mathrm{NiFe}_{2} \mathrm{O}_{4} @$ TEOS-TPS@Ag were two fold diluted (1000, 500, 250, 125, 62.5 and 31 $\mu \mathrm{g} / \mathrm{mL}$ ) with PBS. Then, $20 \mu \mathrm{L}$ from each of the diluted solutions was added to $180 \mu \mathrm{L}$ of the nutrient broth in tubes containing each of the standardized bacterial suspensions $\left(10^{6} \mathrm{CFU} / \mathrm{mL}\right)$. All tubes were incubated at $37^{\circ} \mathrm{C}$ for $24 \mathrm{~h}$. The highest diluted solution with no observable growth was recorded as the MIC. The diluted tubes without growing were plated onto the nutrient agar $\left(100 \mu \mathrm{L}\right.$ from each tube) and incubated at $37^{\circ} \mathrm{C}$ for $24 \mathrm{~h}$. This was used for determining the MBC. The MBC value was recorded for the highest dilutions with no observable growth on the nutrient agar.

\subsection{Recyclability of the $\mathrm{NiFe}_{2} \mathrm{O}_{4} @$ TEOS-TPS@Ag nanocomposite}

The $\mathrm{NiFe}_{2} \mathrm{O}_{4} @$ TEOS-TPS@Ag nanocomposite $(20.0 \mathrm{mg}$ ) was incubated with both Bacillus cereus and Escherichia coli bacteria suspensions $(5 \mathrm{~mL})$ in a conical tube at $37{ }^{\circ} \mathrm{C}$ for $120 \mathrm{~min}$, with $200 \mathrm{rpm}$. After $24 \mathrm{~h}$ of incubation, the tube was located in a magnetic separation stand at room temperature for $10 \mathrm{~min}$. The nanocomposites were attracted to the 
wall of the tube via the magnetic force. After removing the supernatant from the tube, $0.1 \mathrm{~mL}$ of the supernatant was diluted properly and plated onto the agar plates. Each viable bacterium formed into a bacterial colony was counted after being incubated at $37{ }^{\circ} \mathrm{C}$ for $24 \mathrm{~h}$. The recycled magnetite nanocomposites were incubated with a fresh sample of $5 \mathrm{~mL}$ of the suspension in the tube under the same conditions. The methods described above were repeated by employing the same procedures five more times. In each cycle, the magnetic nanocomposites were collected only by exposure to the external magnetic field without washing with any solvents or water.

\section{Results and discussion}

\subsection{XRD analysis}

The XRD profiles of $\mathrm{NiFe}_{2} \mathrm{O}_{4} @ \mathrm{Ag}, \mathrm{NiFe}_{2} \mathrm{O}_{4} @ \mathrm{TEOS}-\mathrm{TPS} a n d \mathrm{NiFe}_{2} \mathrm{O}_{4} @ \mathrm{TEOS}-$ TPS@Ag nanocomposites have been plotted in Fig. 1. In Fig. 1 (a), the four characteristic peaks at $38.5^{\circ}, 44.5^{\circ}, 64.5^{\circ}$ and 78.1 ; and six peaks at $30.3^{\circ}, 35.65^{\circ}, 43.26^{\circ}, 53.61^{\circ}, 57.16^{\circ}$ and $62.74^{\circ}$ are assigned to Ag NPs and $\mathrm{NiFe}_{2} \mathrm{O}_{4}$, respectively. The (hkl) planes of the Ag NPs in (111), (200), (220) and (311) indices showed that the silver arrangement at the surface of the nanomagnetite was face-centered cubic $(f c c)$ [40]. For $\mathrm{NiFe}_{2} \mathrm{O}_{4}$, the (hkl) planes of (220), (311), (400), (422), (511) and (440) were consistent with the previous studies [41, 42]. As regarding, the TEOS-TPS has only a wide peak at $22^{\circ}[43,44]$; therefore Figs 1 . (a) \& (c) exhibit the same XRD patterns of $\mathrm{NiFe}_{2} \mathrm{O}_{4}$ and $\mathrm{Ag}$ NPs. As for characteristic peaks of $\mathrm{Ag}$ NPs

in Figs 1. (a) \& (c), the $f c c$ symmetry structure of Ag NPs was maintained in the synthesize procedure of $\mathrm{NiFe}_{2} \mathrm{O}_{4} @$ TEOS-TPS@ $\mathrm{Ag}$ nanocomposite. There was agreement between the visible diffraction peaks of $\mathrm{NiFe}_{2} \mathrm{O}_{4}$ and the characteristic diffraction of spinel $\mathrm{NiFe}_{2} \mathrm{O}_{4}$ standard data, as shown in JCPDS 44-1485. The sharp peaks in $\mathrm{NiFe}_{2} \mathrm{O}_{4}$ pattern indicated that 
high crystalline $\mathrm{NiFe}_{2} \mathrm{O}_{4}$ had been formed and its coating with TEOS-TPS had no effect on the spinel structure of the $\mathrm{NiFe}_{2} \mathrm{O}_{4}$ magnetic core.

By using of the Scherrer equation, the average crystalline size of $\mathrm{NiFe}_{2} \mathrm{O}_{4} @ \mathrm{TEOS}-$ TPS@Ag nanocomposite was obtained 42 nm.

$D=K \lambda / \beta \cos \theta$

where ' $D$ ', ' $\lambda$ ', ' $\beta$ ' and ' $\theta$ ' are the average crystalline size, $X$-ray source wavelength $(0.1541$ $\mathrm{nm})$, the full width half maximum (FWHM) and the Bragg angle, respectively; and ' $\mathrm{K}$ '= 1 .

Fig. 1. The XRD pattern of as-synthesized nanocomposites.

\subsection{FE-SEM analysis}

The FE-SEM was used to determine the morphology of nanomaterials. As shown in Fig. 2, it could be concluded that uncoated $\mathrm{NiFe}_{2} \mathrm{O}_{4}$ and $\mathrm{NiFe}_{2} \mathrm{O}_{4} @$ TEOS-TPS nanoparticles had a agglomerated cloudy and spongy porous bubble structure, respectively, which was the characteristic of citrate-gel synthesis [45]. The FE-SEM micrograph of $\mathrm{NiFe}_{2} \mathrm{O}_{4} @$ TEOSTPS@Ag nanocomposites showed the distribution of them with few agglomerates containing the well sphere-like nanostructures. This could be due to the coating of TEOS-TPS on the surface of $\mathrm{NiFe}_{2} \mathrm{O}_{4}$ nanoparticles. The histogram profile of the decorated $\mathrm{Ag}$ NPs on the synthesized nanocomposite has been plotted in Fig. 3; the averaged diameter size of the spherical Ag nanoparticles on the surface of the TEOS-TPS matrix was obtained to be $36 \mathrm{~nm}$.

Fig. 2. The FE-SEM images of as-synthesized nanocomposites.

Fig. 3. The size distribution of Ag NPs in the as-synthesized nanocomposite. 


\subsection{TEM Analysis}

TEM observation of the $\mathrm{NiFe}_{2} \mathrm{O}_{4} @ \mathrm{TEOS}-\mathrm{TPS} @ \mathrm{Ag}$ composite was carried out to explore the morphological and structural landscapes of these nanocomposites. It can be concluding from Fig. 4 that the surface of $\mathrm{NiFe}_{2} \mathrm{O}_{4}$ nanoparticles was decorated with TEOSTPS and Ag NPs. The averaged particles size of decorated nanocomposite was estimated 46.5 nm.

Fig. 4. The TEM image of $\mathrm{NiFe}_{2} \mathrm{O}_{4} @ \mathrm{TEOS}-\mathrm{TPS} @ \mathrm{Ag}$ nanocomposites.

\subsection{FT-IR spectra analysis}

In Fig. 5.the FT-IR spectra of $\mathrm{NiFe}_{2} \mathrm{O}_{4} @ \mathrm{TEOS}-\mathrm{TPS}$ and $\mathrm{NiFe}_{2} \mathrm{O}_{4} @ \mathrm{TEOS}-\mathrm{TPS} @ \mathrm{Ag}$ nanocomposites in the range of 2500 to $400 \mathrm{~cm}^{-1}$ at room temperature have been scanned. The FT-IR spectrum of $\mathrm{NiFe}_{2} \mathrm{O}_{4}$ has not been shown; this can be seen in the reference [14]. The main absorption bands at around 453 and $579 \mathrm{~cm}^{-1}$ were assigned to the intrinsic stretching vibrations of Fe ions in octahedral and tetrahedral of spinel structure sites. The peak at 579 $\mathrm{cm}^{-1}$ overlaid with characteristic peak at $595 \mathrm{~cm}^{-1}$ that observed in both spectra. The assignment of the different peaks of TEOS-TPS at around $595 \mathrm{~cm}^{-1}(\mathrm{C}-\mathrm{S}), 1153$ and 949 $\mathrm{cm}^{-1}$ ( $\mathrm{Si}-\mathrm{O}-\mathrm{C}$ bond) [46] could be observed in Fig. 5. The strong peak at $1096 \mathrm{~cm}^{-1}$ was assigned to the asymmetric stretching vibration of $\mathrm{Si}-\mathrm{O}-\mathrm{Si}[47,48]$. However, as could be observed in this Figure, the FT-IR spectrum of $\mathrm{NiFe}_{2} \mathrm{O}_{4} @$ TEOS-TPS@Ag nanocomposite exhibited all characteristic peaks of TEOS-TPS, in addition to the $\mathrm{Fe}-\mathrm{O}$ stretching vibrations $[41,42]$. The $\mathrm{C}-\mathrm{O}$ stretching vibration of carbonyl group was assigned to the strong peak at $1650 \mathrm{~cm}^{-1}$. In comparison with Figs. 5 (a) \& (b), the reducing of peaks at around 595 showed that this new nanocomposite was formed. The reason for this was that silver had been linked with sulfur. 
Fig. 5.The FT-IR spectra of $\mathrm{NiFe}_{2} \mathrm{O}_{4} @$ TEOS-TPS (a) and $\mathrm{NiFe}_{2} \mathrm{O}_{4} @$ TEOS-TPS@ $\mathrm{Ag}(\mathrm{b})$.

\subsection{The VSM results}

The magnetic properties of all synthesized nanocomposites were studied by VSM at room temperature. The VSM magnetization curves of the $\mathrm{NiFe}_{2} \mathrm{O}_{4}$ nanoparticles, $\mathrm{NiFe}_{2} \mathrm{O}_{4} @$ TEOS-TPS and $\mathrm{NiFe}_{2} \mathrm{O}_{4} @$ TEOS-TPS@Ag nanocomposites are exhibited in Fig. 6. The saturation magnetization $\left(\mathrm{M}_{\mathrm{s}}\right)$, remnant magnetization $\left(\mathrm{M}_{\mathrm{r}}\right)$ and the coercivity $\left(\mathrm{H}_{\mathrm{c}}\right)$ of these synthesized materials were determined from the hysteresis loops measurements, as presented in Table 1. Regarding this data, the values of $\mathrm{M}_{\mathrm{s}}, \mathrm{M}_{\mathrm{r}}$ and $\mathrm{H}_{\mathrm{c}}$ for $\mathrm{NiFe}_{2} \mathrm{O}_{4} @ \mathrm{TEOS}-$ TPS nanocomposite (Fig. 6 b) were less than those gained for the pure $\mathrm{NiFe}_{2} \mathrm{O}_{4}$. Also, the decrease in the magnetic nature of the naked ferrite was noticed for the three-component $\mathrm{NiFe}_{2} \mathrm{O}_{4} @$ TEOS-TPS@Ag nanocomposite (Fig. $6 \mathrm{c}$ ). The decrease in the magnetic property of the produced new nanocomposite was due to the TEOS-TPS and Ag NPs layers that acted as the magnetic dead layers. Thus, more decrease in the magnetic nature of $\mathrm{NiFe}_{2} \mathrm{O}_{4} @ \mathrm{TEOS}-$ TPS@Ag could be predictable in comparison of $\mathrm{NiFe}_{2} \mathrm{O}_{4} @$ TEOS-TPS. The slight increase in the coercivity $\left(\mathrm{H}_{\mathrm{c}}\right)$ value for $\mathrm{NiFe}_{2} \mathrm{O}_{4} @$ TEOS-TPS@ $\mathrm{Ag}$ could be attributed to the anisotropy of the surface coating $[39,49]$.

Fig. 6. The VSM profiles of as--synthesized nanocomposites.

Table 1 The magnetic parameters of as-prepared nanocomposites.

\subsection{Antibacterial activity}


As can be observed from the data in Table 2 and figure 7, the immobilization of $\mathrm{Ag}$ nanoparticles onto the TEOS-TPS matrix of the nanocomposite could retain their antibacterial activity. Of course, it was predictable that the cytotoxic effect of the immobilized Ag NPs on mammalian cells would be less than that of free silver nanoparticles because of the slow release of silver ions from the TEOS-TPS matrix.

Fig. 7. The inhibition Zone of 1: Distilled water, 2: $\mathrm{NiFe}_{2} \mathrm{O}_{4}, 3: \mathrm{NiFe}_{2} \mathrm{O}_{4} @$ TPS-TEOS and 4: $\mathrm{NiFe}_{2} \mathrm{O}_{4} @ \mathrm{TPS}-\mathrm{TEOS} @ \mathrm{Ag}$ against tested bacteria.

Table 2 The inhibition Zone ( $\mathrm{mm}$ ) of Blank disk and as-prepared of nanocomposites against tested bacteria.

\subsection{MIC and MBC results}

The MICs and MBCs values of $\mathrm{NiFe}_{2} \mathrm{O}_{4} @$ TEOS-TPS@Ag nanocomposite against the tested bacteria are listed in Table 3.The as-synthesized nanocomposite showed MICs values from 5.40 to $21.50 \mathrm{mg} / \mathrm{mL}$ against gram-positive ( $S$. aureus, B. cereus) bacteria and 5.40 to $10.80 \mathrm{mg} / \mathrm{mL}$ against gram-negative (S. typhimurium, E. coli) bacteria. The values of determined MBCs were in a range of 10 to $43 \mathrm{mg} / \mathrm{mL}$ for the nanocomposite powder. The $\mathrm{MBC} / \mathrm{MIC}$ ratio values were $\leq 4$, showing that $\mathrm{NiFe}_{2} \mathrm{O}_{4} @ \mathrm{TEOS}-\mathrm{TPS} @ \mathrm{Ag}$ nanocomposite had a bactericidal effect against the mentioned bacterial strains $[50,51]$.

Table 3 The MIC and MBC parameters of as-prepared of Ag nanocomposites.

\subsection{Recyclability}


The recyclable antibacterial activity of $\mathrm{NiFe}_{2} \mathrm{O}_{4} @$ TEOS-TPS coated with Ag NPs was obtained. It was found that the bacterial killing efficiency was not changed after contact with the same magnetic nanoparticles through five cycles for $\mathrm{NiFe}_{2} \mathrm{O}_{4} @ \mathrm{TEOS}-\mathrm{TPS} @ \mathrm{Ag}$. The bactericidal efficiency of the $\mathrm{NiFe}_{2} \mathrm{O}_{4} @ \mathrm{TEOS}-\mathrm{TPS} @ \mathrm{Ag}$ nanocomposite remained around $100 \%$ for both $S$. aureus and $E$. coli of the first three cycles. The antibacterial activity was reduced by $10 \%$ for both bacterial strains after 5 repeated usages. Sureshkumar et.al [52] and Pinto coworkers [53] have been reported that the decrease in the antimicrobial activity was due to two effects: escape of Ag NPs during incubation in bacterial solution and/or the active Ag surface being covered by proteins and nucleic acids released from the killed bacterial cells.

\subsection{The BET results}

The surface area of the prepared nanomaterials was evaluated by using single-point Brunauer-Emmett-Teller (BET; NanoSord, Iran) method. The surface area of the $\mathrm{NiFe}_{2} \mathrm{O}_{4}$, $\mathrm{NiFe}_{2} \mathrm{O}_{4} @$ TEOS-TPS and $\mathrm{NiFe}_{2} \mathrm{O}_{4} @$ TEOS-TPS@Ag was gained to be 74.2, 27.9 and 26.7 $\mathrm{m}^{2} / \mathrm{g}$, respectively. By increasing the particle size of as-synthesized nanocomposites, the BET was reduced due to pores size on the surface of nanocomposite [54]. This showed the available surface of these nanocomposites was decreased with increasing their particle size.

\section{Conclusion}

The sol-gel method was used for the synthesis of the TEOS-TPS matrix that covered $\mathrm{NiFe}_{2} \mathrm{O}_{4}$ core for the formation of $\mathrm{NiFe}_{2} \mathrm{O}_{4} @$ TEOS-TPS nanocomposite. By coating the $\mathrm{NiFe}_{2} \mathrm{O}_{4} @ \mathrm{TEOS}-\mathrm{TPS} \quad$ with the silver nanoparticles, $\mathrm{NiFe}_{2} \mathrm{O}_{4} @ \mathrm{TEOS}-\mathrm{TPS} @ \mathrm{Ag}$ nanocomposite was prepared. Some spectroscopic methods such as FT-IR, XRD, FE-SEM and TEM proved the formation of the three components of $\mathrm{NiFe}_{2} \mathrm{O}_{4} @$ TEOS-TPS@ $\mathrm{Ag}$ nanocomposite. The VSM method was applied for evaluating the magnetic properties of these 
nanocomposites, showing that the non-magnetic layers of TEOS-TPS and Ag NPs decreased the natural magnetic ferrite. Of course, this reduction was impalpable for layer's TEOS-TPS, as compared with its Ag NPs; and it could be an advantage for removing $\mathrm{NiFe}_{2} \mathrm{O}_{4} @$ TEOSTPS nanocomposite from media. However, by applying the magnetite field, all as-prepared nanocomposites were simply removed from the media. The new nanocomposites showed the convenient antibacterial activity. Also, the $\mathrm{MBC} / \mathrm{MIC}$ ratio values were $\leq 4$, indicating that $\mathrm{NiFe}_{2} \mathrm{O}_{4} @$ TEOS-TPS@Ag nanocomposite had a bactericidal effect against the various bacterial strains. The disinfection activity of $\mathrm{NiFe}_{2} \mathrm{O}_{4} @$ TEOS-TPS@ Ag nanocomposite had no apparent decrease after five-time recycle reusability. Therefore, this new as-prepared nanocomposite could have potential application in water disinfection and as regarding to specified the corrosion rate decreases in nano nickel ferrite $\left(\mathrm{NiFe}_{2} \mathrm{O}_{4}\right)$, this structure can be more suitable than $\mathrm{Fe}_{3} \mathrm{O}_{4}$ for industrial application i.e. economically and efficiently $[15,16]$.

\section{Acknowledgements:}

This work has been financially supported by Iran National Science Foundation, INSF (Project No. 94016129) and Center of Excellency in Applied Nanotechnology. 


\section{References:}

[1] Y. Zhu, N.S. Hosmane, Nanocatalysis: Recent advances and applications in boron chemistry, Coordination Chemistry Reviews, 293 (2015) 357-367.

[2] P.C. Naha, P. Chhour, D.P. Cormode, Systematic in vitro toxicological screening of gold nanoparticles designed for nanomedicine applications, Toxicology in Vitro, 29 (2015) 1445-1453.

[3] S.M. Ladjevardi, A. Asnaghi, P.S. Izadkhast, A.H. Kashani, Applicability of graphite nanofluids in direct solar energy absorption, Solar Energy, 94 (2013) 327-334.

[4] I. Plans, A. Carpio, L.L. Bonilla, Toy nanoindentation model and incipient plasticity, Chaos, Solitons \& Fractals, 42 (2009) 1623-1630.

[5] W. Zhang, Y. Yao, N. Sullivan, Y.S. Chen, Modeling the primary size effects of citrate-coated silver nanoparticles on their ion release kinetics, Environ. Sci. Technol, 45 (10) (2011) $4422-4428$.

[6] R. Ma, C. Levard, S.M. Marinakos, Y.W. Cheng, J. Liu, F.M. Michel, G.E. Brown, G.V. Lowry, Size-controlled dissolution of organic-coated silver nanoparticles, Environ. Sci. Technol., 46 (2012) $752-759$.

[7] E. Navarro, F. Piccapietra, B. Wagner, F. Marconi, R. Kaegi, N. Odzak, L. Sigg, R. Behra, Toxicity of silver nanoparticles to Chlamydomonas reinhardtii, Environ. Sci. Technol, 42 (23) (2008) 8959-8964.

[8] J. Fabrega, S.R. Fawcett, J.C. Renshaw, J.R. Lead, Silver nanoparticle impact on bacterial growth: Effect of pH, concentration, and organic matter., Environ. Sci. Technol, 43 (19) (2009) $7285-7290$.

[9] V.K. Sharma, R.A. Yngard, Y. Lin, Silver nanoparticles: green synthesis and their antimicrobial activities, Advances in Colloid and Interface Science, 145 (2009) 83-96.

[10] A. Amarjargal, L.D. Tijing, I.-T. Im, C.S. Kim, Simultaneous preparation of $\mathrm{Ag} / \mathrm{Fe}_{3} \mathrm{O}_{4}$ core-shell nanocomposites with enhanced magnetic moment and strong antibacterial and catalytic properties, Chemical Engineering Journal, 226 (2013) 243-254. 
[11] M. Kooti, S.Saiahi, H. Motamedi, Fabrication of silver-coated cobalt ferrite nanocomposite and the study of its antibacterial activity, J. Magn. Magn. Mater., 333 (2013) 138-143.

[12] Q. He, J. Liu, J. Liang, C. Huang, W. Li, Synthesis and antibacterial activity of magnetic $\mathrm{MnFe}_{2} \mathrm{O}_{4} / \mathrm{Ag}$ composite particles, Nanoscience and Nanotechnology Letters, 6 (2014) 385-391.

[13] M. Kooti, P.Kharazi, H. Motamedi, Preparation, characterization, and antibacterial activity of $\mathrm{CoFe}_{2} \mathrm{O}_{4} /$ polyaniline/Ag nanocomposite, J. Taiwan Inst. Chem. E, 45 (2014) 2698-2704.

[14] A. Allafchian, H. Bahramian, S.A.H. Jalali, H. Ahmadvand, Synthesis, characterization and antibacterial effect of new magnetically core-shell nanocomposites, Journal of Magnetism and Magnetic Materials, 394 (2015) 318-324.

[15] S.A. Nightingale, R.J. Longbottom, B.J. Monaghan, Corrosion of nickel ferrite refractory by $\mathrm{Na}_{3} \mathrm{AlF}_{6}-\mathrm{AlF}_{3}-\mathrm{CaF}_{2}-\mathrm{Al}_{2} \mathrm{O}_{3}$ bath, Journal of the European Ceramic Society, 33 (2013) 2761-2765.

[16] A.U. Chaudhry, V. Mittal, B. Mishra, Nano nickel ferrite $\left(\mathrm{NiFe}_{2} \mathrm{O}_{4}\right)$ as anti-corrosion pigment for API 5L X-80 steel: An electrochemical study in acidic and saline media, Dyes and Pigments, 118 (2015) 18-26.

[17] T. Mosaiab, C.J. Jeong, G.J. Shin, K.H. Choi, S.K. Lee, I. Lee, I. In, S.Y. Park, Recyclable and stable silver deposited magnetic nanoparticles with poly (vinyl pyrrolidone)-catechol coated iron oxide for antimicrobial activity, Materials Science and Engineering, 33 (2013) 3786-3794.

[18] S. Sa'nchez-Valdes, H. Ortega-Ortiz, L.F. Ramos-de Valle, F.J. Medellı'n-Rodri'guez, R. Guedea-Miranda, Mechanical and antimicrobial properties of multilayer films with a polyethylene/silver nanocomposite layer, Journal of Applied Polymer Science, 111 (2) (2009) 953-962.

[19] M. Marini, S.D. Niederhausern, R. Iseppi, M. Bondi, C. Sabia, M. Toselli, F. Pilati, Antibacterial Activity of Plastics Coated with Silver-Doped Organic-Inorganic Hybrid Coatings Prepared by Sol-Gel Processes, Biomacromolecules, 8 (2007) 1246-1254.

[20] A. Salam, B. Banerjee, A.S. Roy, P. Mondal, S. Roy, A. Bhaumik, S.M. Islam, Silver nanoparticles embedded over mesoporous organic polymer ashighly efficient and reusable 
nanocatalyst for the reduction ofnitroarenes and aerobic oxidative esterification of alcohols, Applied Catalysis A: General, 477 (2014) 184-194.

[21] Y. Xie, Z. Fang, X. Qiu, E.P. Tsang, B. Liang, Comparisons of the reactivity, reusability and stability of four different zero-valent iron-based nanoparticles, Chemosphere, 108 (2014) 433436.

[22] J.R. Morones, J.L. Elechiguerra, A. Camacho, K. Holt, J.B. Kouri, J.T. Ramírez, M.J. Yacaman, The bactericidal effect of silver nanoparticles., Nanotechnology, 16(10) (2005) 2346-2353.

[23] L. Guo, J. Bai, J. Wang, H. Liang, C. Li, W. Sun, Q. Meng, Fabricating series of controllableporosity carbon nanofibers-based palladium nanoparticles catalyst with enhanced performances and reusability, Journal of Molecular Catalysis A: Chemical, 400 (2015) 95-103.

[24] F.-P. Ma, P.-H. Li, B.-L. Li, L.-P. Mo, N. Liu, H.-J. Kang, Y.-N. Liu, Z.-H. Zhang, A recyclable magnetic nanoparticles supported antimony catalyst for the synthesis of $\mathrm{N}$-substituted pyrroles in water, Applied Catalysis A: General, 457 (2013) 34-41.

[25] Y.L. Pang, A.Z. Abdullah, Effect of low $\mathrm{Fe}^{3+}$ doping on characteristics, sonocatalytic activity and reusability of $\mathrm{TiO}_{2}$ nanotubes catalysts for removal of Rhodamine $\mathrm{B}$ from water, Journal of Hazardous Materials, 235-236 (2012) 326-335.

[26] T.-H. Le, S.J. Kim, S.H. Bang, S.-H. Lee, Y. Woo Choi, P. Kim, Y.-H. Kim, J. Min, Phenol degradation activity and reusability of Corynebacterium glutamicum coated with $\mathrm{NH}_{2-}$ functionalized silica-encapsulated $\mathrm{Fe}_{3} \mathrm{O}_{4}$ nanoparticles, Bioresource Technology, 104 (2012) 795 798.

[27] A. Shahverdi, A. Fakhimi, H. Shahverdi, S. Minaian, Synthesis and effect of silver nanoparticles on the antibacterial activity of different antibiotics against Staphylococcus aureus and Escherichia coli, Nanomedicine: Nanotechnology, Biology and Medicine 3 (2) (2007) 168-171.

[28] C. Zhang, X. Wang, J. Sun, T. Kou, Z. Zhang, Synthesis and antibacterial properties of magnetically recyclable nanoporous silver/ $/ \mathrm{Fe}_{3} \mathrm{O}_{4}$ nanocomposites through one-step dealloying, Cryst. Eng. Comm., 15 (2013) 3965-3973. 
[29] L. Lin, H. Cui, G. Zeng, M. Chen, H. Zhang, M. Xu, X. Shen, C. Bortolini, M. Dong, Ag$\mathrm{CuFe}_{2} \mathrm{O}_{4}$ magnetic hollow fibers for recyclable antibacterial materials, Journal of Materials Chemistry B, 1 (2013) 2719-2723.

[30] L. Liu, Z. Liu, H. Bai, D.D. Sun, Concurrent filtration and solar photocatalytic disinfection/degradation using high-performance $\mathrm{Ag} / \mathrm{TiO}_{2}$ nanofiber membrane, Water Res., 46 (2012) 1101-1112.

[31] H. WA, B. EF, M. GJ, Inactivation credit of UV radiation for viruses, bacteria and protozoan (oo)cysts in water: a review, Water Res., 40 (2006) 3-22.

[32] J.J. Huang, H.Y. Hu, F. Tang, Y. Li, S.Q. Lu, Y. Lu, Inactivation and reactivation of antibioticresistant bacteria by chlorination in secondary effluents of a municipal wastewater treatment plant, Water Res., 45 (2011) 2775-2781.

[33] J. Süb, S. Volz, U. Obst, T. Schwartz, Application of a molecular biology concept for the detection of DNA damage and repair during UV disinfection, Water Res., 43 (2009) 3705-3716.

[34] A.A. Ensafi, B. Arashpour, B. Rezaei, A.R. Allafchian, Voltammetric behavior of dopamine at a glassy carbon electrode modified with $\mathrm{NiFe}_{2} \mathrm{O}_{4}$ magnetic nanoparticles decorated with multiwall carbon nanotubes, Mater. Sci. Eng. C, 39 (2014) 78-85.

[35] A.R. Allafchian, S.A.H. Jalali, Synthesis, characterization and antibacterial effect of poly (acrylonitrile/maleic acid)-silver nanocomposite, Journal of the Taiwan Institute of Chemical Engineers, 57 (2015) 154-159.

[36] K. Varaprasad, Y.M. Mohan, S. Ravindra, N.N. Reddy, K. Vimala, K. Monika, B. Sreedhar, K.M. Raju, Hydrogel-silver nanoparticle composites: a new generation of antimicrobials, J. Appl. Polym. Sci., 115 (2010) 1199-1207.

[37] L. Mai, D. Wang, S. Zhang, Y. Xie, C. Huang, Z. Zhang, Synthesis and bactericidal ability of $\mathrm{Ag} / \mathrm{TiO}_{2}$ composite films deposited on titanium plate, Applied Surface Science, 257 (2010) 974978.

[38] A.A. Farghali, M. Moussa, M.H. Khedr, Synthesis and characterization of novel conductive and magnetic nano-composites, J. Alloy. Compd., 499 (2010) 98-103. 
[39] K.H. Wu, Y.M. Shin, C.C. Yang, W.D. Ho, J.S. Hsu, Preparation and ferromagnetic properties of $\mathrm{Ni}_{0.5} \mathrm{Zn}_{0.5} \mathrm{Fe}_{2} \mathrm{O}_{4} /$ polyaniline core-shell nanocomposites, Journal of Polymer Science Part A: Polymer Chemistry, 44 (2006) 2657-2664.

[40] S.A.H. Jalali, A.R. Allafchian, Assessment of antibacterial properties of novel silver nanocomposite, Journal of the Taiwan Institute of Chemical Engineers, 59 (2016) 506-513.

[41] A.A. Ensafi, F. Saeid, B. Rezaei, A.R.Allafchian, $\mathrm{NiFe}_{2} \mathrm{O}_{4}$ nanoparticles decorated with MWCNTs as a selective and sensitive electrochemical sensor for the determination of epinephrine using differential pulse voltammetry, Anal. Methods, 6 (2014) 6885-6892.

[42] M.Z.K. S. Sultana, K.Umar, Synthesis and characterization of copper ferrite nanoparticles doped polyaniline, J. Alloy. Compd., 535 (2012) 44-49.

[43] S. Gu, J. Zhou, Z. Luo, Q. Wang, M. Ni, A detailed study of the effects of pyrolysis temperature and feed stock particle size on the preparation of nanosilica from rice husk, Industrial Crops and Products, 50 (2013) 540-549.

[44] B.A. Lyon, A.D. Dotson, K.G. Linden, H.S. Weinberg, The effect of inorganic precursors on disinfection byproduct formation during UV-chlorine/chloramine drinking water treatment, Water Research, 46 (2012 ) 4653-4664.

[45] A. Hassen, M. Mahrouk, H. Ouzari, M. Cherif, B. Technol, UV disinfection of treated wastewater in a large-scale pilot plant and inactivation of selected bacteria in a laboratory UV device, Bioresource Technology, 74 (2000) 141-150.

[46] I.R. Hill, I.W. Levin, Vibrational spectra and carbon-hydrogen stretching mode assignments for a series of n-alkyl carboxylic acids, J. Chem. Phys., 70 (1979) 842-851.

[47] F. Zucchi, A. Frignani, V. Grassi, G. Trabanelli, M. Dalcolle, The formation of a protective layer of 3-mercapto-propyl-trimethoxy-silane on copper corros, Corrosion Science, 49 (2007) 15701583.

[48] A. Lee Smith, Analysis of silicones, Wiley, New York, Chapter 10 (1974).

[49] P. Guo, L. Cui, Y. Wang, M. Lv, B. Wang, X. Zhao, Facile synthesis of $\mathrm{ZnFe}_{2} \mathrm{O}_{4}$ nanoparticles with tunable magnetic and sensing properties, Langmuir, 29 (2013) 8997-9003. 
[50] H.H. Lara, N.V. Ayala-Núnez, L.d.C.I. Turrent, C.R. Padilla, Bactericidal effect of silver nanoparticles against multidrug-resistant bacteria, World Journal of Microbiology and Biotechnology, 26 (2010) 615-621.

[51] P. Murray, F. Witebsky, The clinician and the microbiology laboratory, Principles and Practice of Infectious Diseases. 7th ed. Philadelphia, Pa: Elsevier Churchill Livingstone, (2009).

[52] M. Sureshkumar, D.Y. Siswanto, C.-K. Lee, Magnetic antimicrobial nanocomposite based on bacterial cellulose and silver nanoparticles, Journal of Materials Chemistry, 20 (2010) 6948-6955.

[53] R.J.B. Pinto, P.A.A.P. Marques, C.P. Neto, T. Trindade, S. Daina, P. Sadocco, Antibacterial activity of nanocomposites of silver and bacterial or vegetable cellulosic fibers, Acta Biomaterialia, 5 (2009) 2279-2289.

[54] K.J.A. Raj, B. Viswanathan, Effect of surface area, pore volume and particle size of P25 titania on the phase transformation of anatase to rutile, Indian Journal of Chemistry, 48 (2009) 1378-1382. 
Table 1 The magnetic parameters of as-repared nanocomposites.

\begin{tabular}{lllll}
\hline \hline & Magnetic material & magnetization, & Remnant magnetization, & Coercivity, \\
& Saturation & $\mathrm{M}_{\mathrm{s}}(\mathrm{emu} / \mathrm{g})$ & $\mathrm{M}_{\mathrm{r}}(\mathrm{emu} / \mathrm{g})$ & $\mathrm{H}_{\mathrm{c}}\left(\mathrm{O}_{\mathrm{e}}\right)$ \\
\hline (a) & $\mathrm{NiFe}_{2} \mathrm{O}_{4}$ & $64.8 \pm 0.1$ & $8.7 \pm 0.3$ & $76.0 \pm 0.9$ \\
(b) $\mathrm{NiFe}_{2} \mathrm{O}_{4} @$ TEOS-TPS & $62.4 \pm 0.3$ & $6.0 \pm 0.2$ & $65.9 \pm 1.0$ \\
(c) & $\mathrm{NiFe}_{2} \mathrm{O}_{4} @$ TEOS-TPS@ $\mathrm{Ag}$ & $50.2 \pm 0.2$ & $5.5 \pm 0.2$ & $67.6 \pm 1.1$ \\
\hline \hline
\end{tabular}


Table 2 The inhibition Zone (mm) of Blank disk and as-prepared of nanocomposites against tested bacteria.

\begin{tabular}{llllll}
\hline \hline \multirow{2}{*}{ Compounds } & \multicolumn{4}{c}{ Zone of inhibition $(\mathrm{mm})$ average \pm standard deviation } \\
\cline { 3 - 6 } & & S. aureus & B. cereus & E. coli & S. typhimurium \\
\hline 1 & Distilled water & $6.4 \pm 0.1$ & $6.4 \pm 0.1$ & $6.4 \pm 0.1$ & $6.4 \pm 0.1$ \\
2 & $\mathrm{NiFe}_{2} \mathrm{O}_{4}$ & $6.4 \pm 0.1$ & $6.4 \pm 0.1$ & $6.4 \pm 0.1$ & $6.4 \pm 0.1$ \\
3 & $\mathrm{NiFe}_{2} \mathrm{O}_{4} @ \mathrm{TPS}-\mathrm{TEOS}$ & $6.4 \pm 0.1$ & $6.4 \pm 0.1$ & $6.4 \pm 0.1$ & $6.4 \pm 0.1$ \\
4 & $\mathrm{NiFe}_{2} \mathrm{O}_{4} @ \mathrm{TPS}-\mathrm{TEOS} @ \mathrm{Ag}$ & $10.3 \pm 0.3$ & $10.9 \pm 0.3$ & $10.7 \pm 0.3$ & $11.1 \pm 0.3$ \\
\hline \hline
\end{tabular}


Table 3 The MIC and MBC parameters of as-prepared of Ag nanocomposites.

\begin{tabular}{llll}
\hline \hline \multirow{2}{*}{ Compounds } & \multicolumn{3}{l}{$\mathrm{NiFe}_{2} \mathrm{O}_{4} @$ TEOS-TPS@ Ag } \\
\cline { 2 - 4 } & $\mathrm{MIC}(\mathrm{mg} / \mathrm{mL})$ & $\mathrm{MBC}(\mathrm{mg} / \mathrm{mL})$ & $\mathrm{MBC} / \mathrm{MIC}$ \\
\hline \hline S. aureus & 5.40 & 10.80 & 2.00 \\
B. cereus & 21.50 & 42.90 & 1.99 \\
E. coli & 10.80 & 21.50 & 1.99 \\
S. typhimurium & 5.40 & 21.50 & 3.98 \\
\hline \hline
\end{tabular}


Fig. 1. The XRD pattern of as-synthesized nanocomposites.

Fig. 2. The FE-SEM images of as--synthesized nanocomposites.

Fig. 3. The size distribution of Ag NPs in the as-synthesized nanocomposite.

Fig. 4. The TEM image of $\mathrm{NiFe}_{2} \mathrm{O}_{4} @ \mathrm{TEOS}-\mathrm{TPS} @ \mathrm{Ag}$ nanocomposites.

Fig. 5. The FT-IR spectra of $\mathrm{NiFe}_{2} \mathrm{O}_{4} @$ TEOS-TPS (a) and $\mathrm{NiFe}_{2} \mathrm{O}_{4} @ \mathrm{TEOS}-\mathrm{TPS} @ \mathrm{Ag}(\mathrm{b})$.

Fig. 6. The VSM profiles of as-synthesized nanocomposites.

Fig.7. The inhibition Zone of 1: Distilled water, 2: $\mathrm{NiFe}_{2} \mathrm{O}_{4}, 3: \mathrm{NiFe}_{2} \mathrm{O}_{4} @$ TPS-TEOS and 4: $\mathrm{NiFe}_{2} \mathrm{O}_{4} @ \mathrm{TPS}-\mathrm{TEOS} @ \mathrm{Ag}$ against tested bacteria. 
Fig. 1

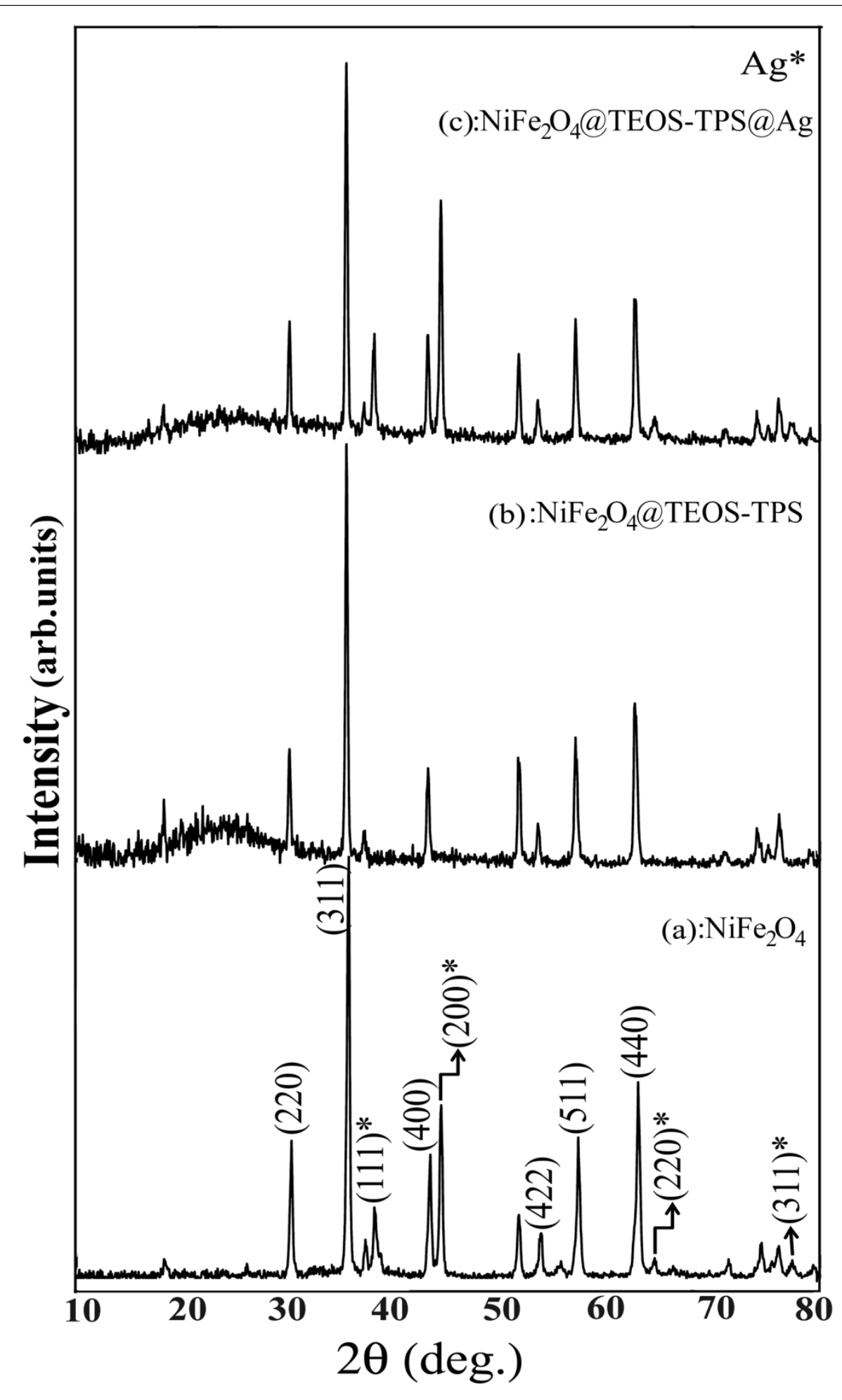


Fig. 2

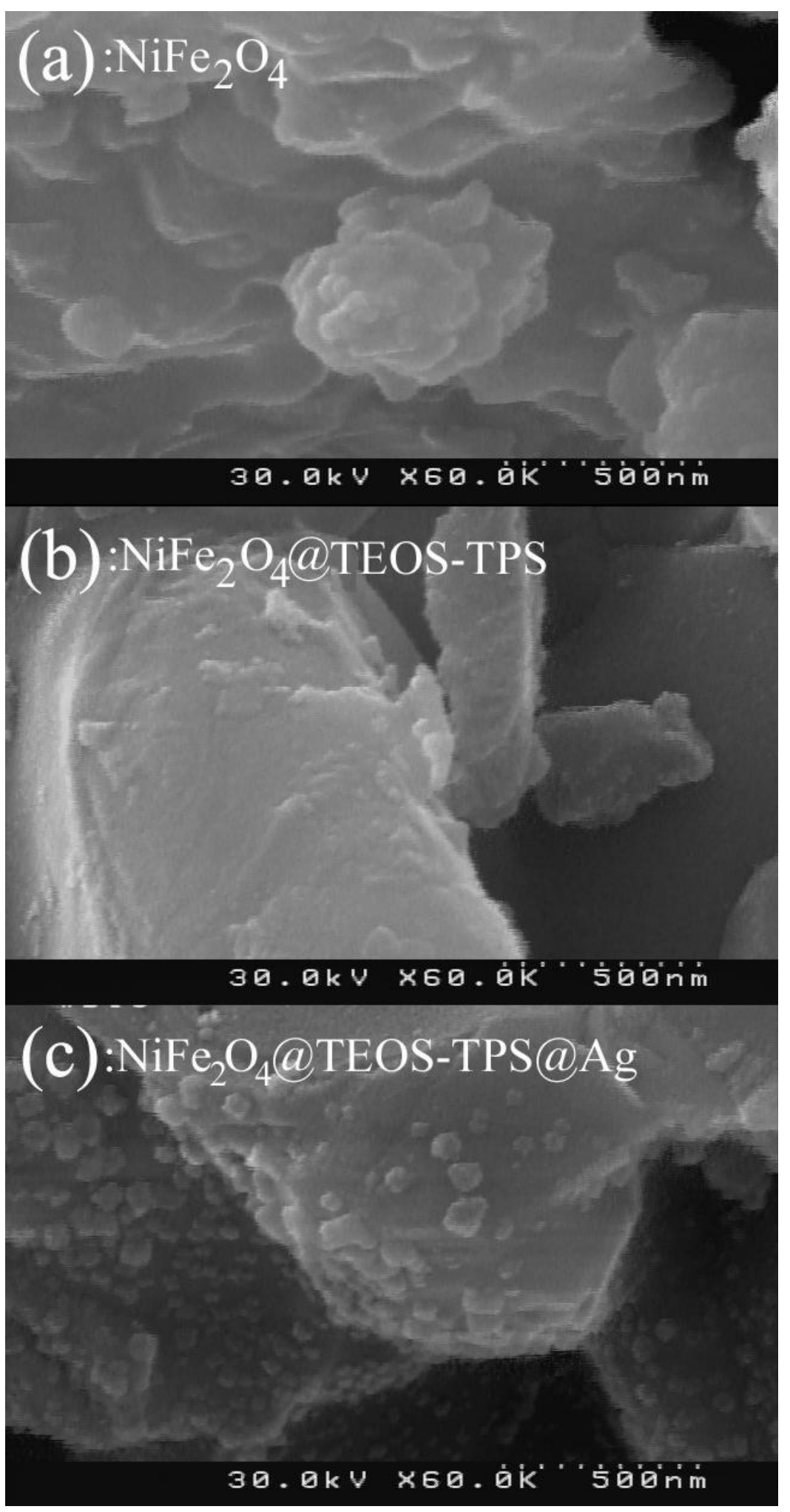


Fig. 3

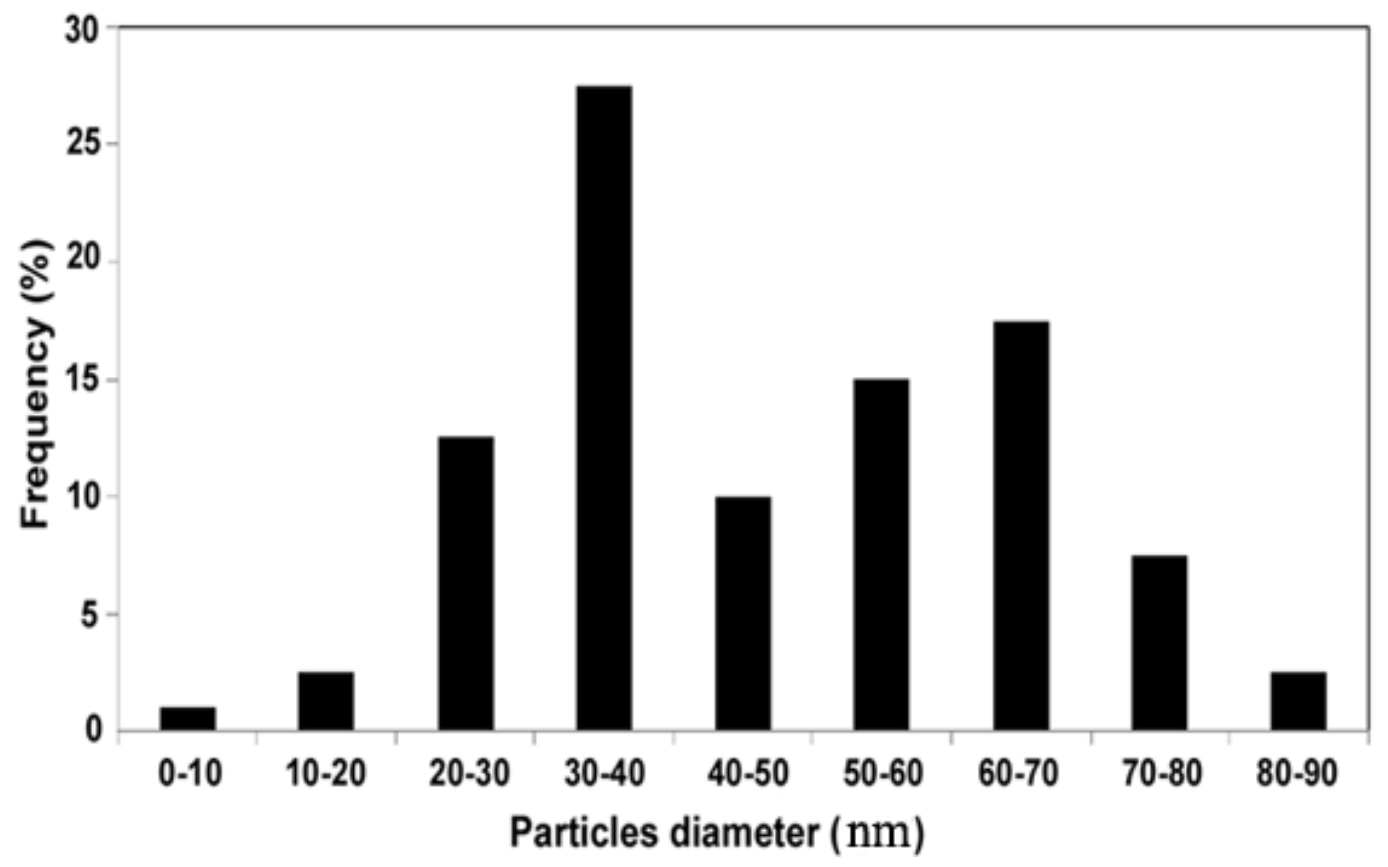


Fig. 4 
Fig. 5

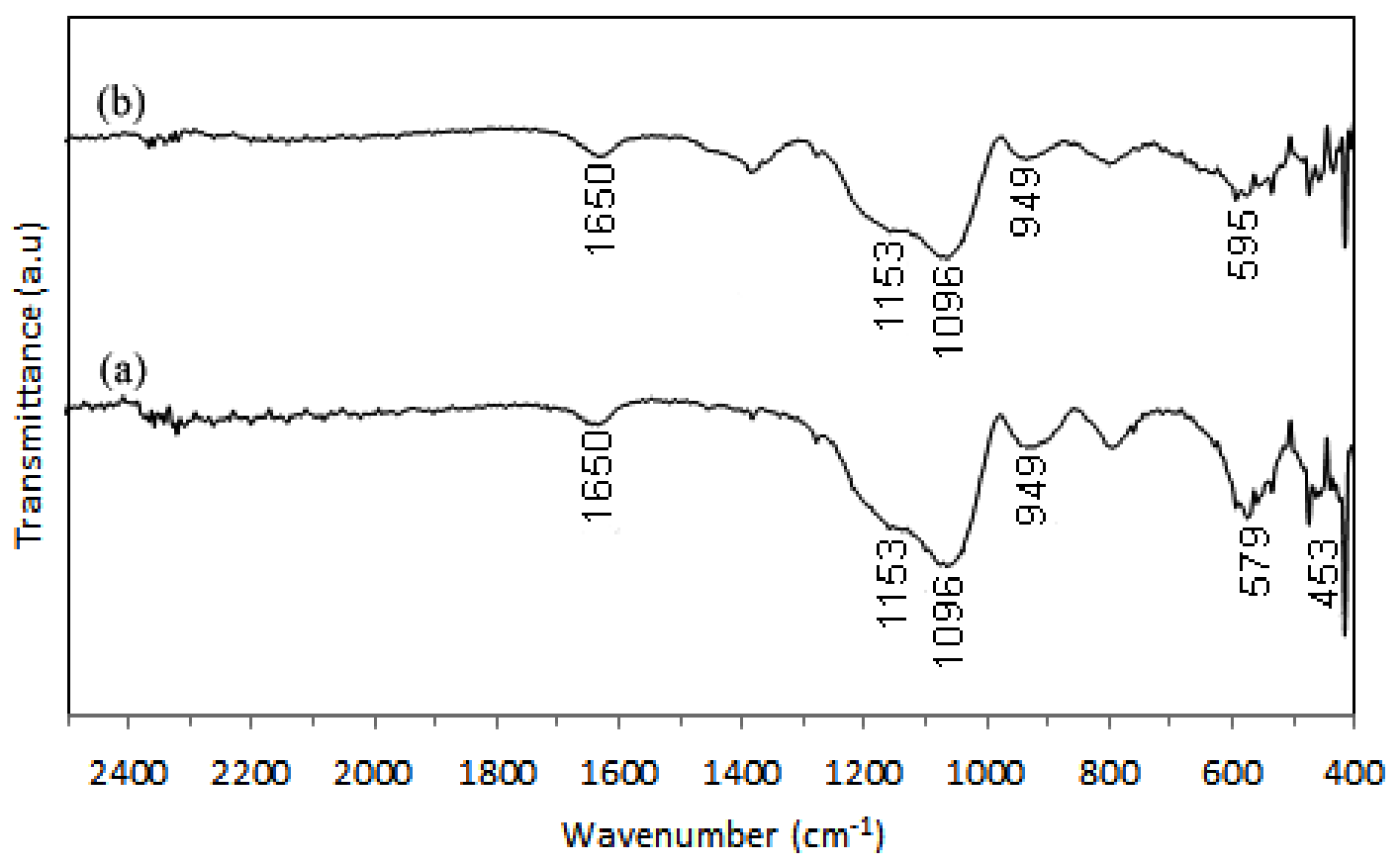


Fig. 6
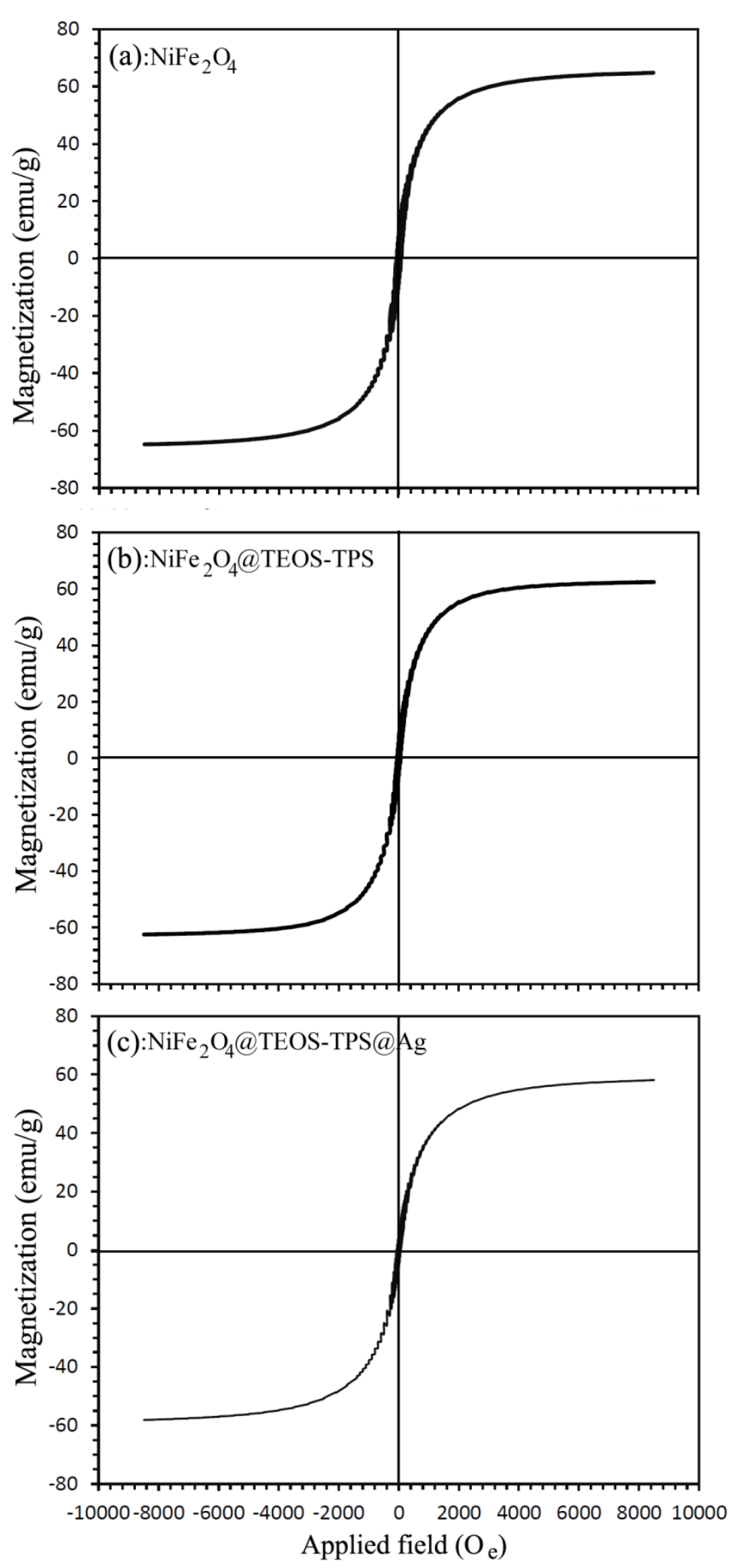
Fig. 7

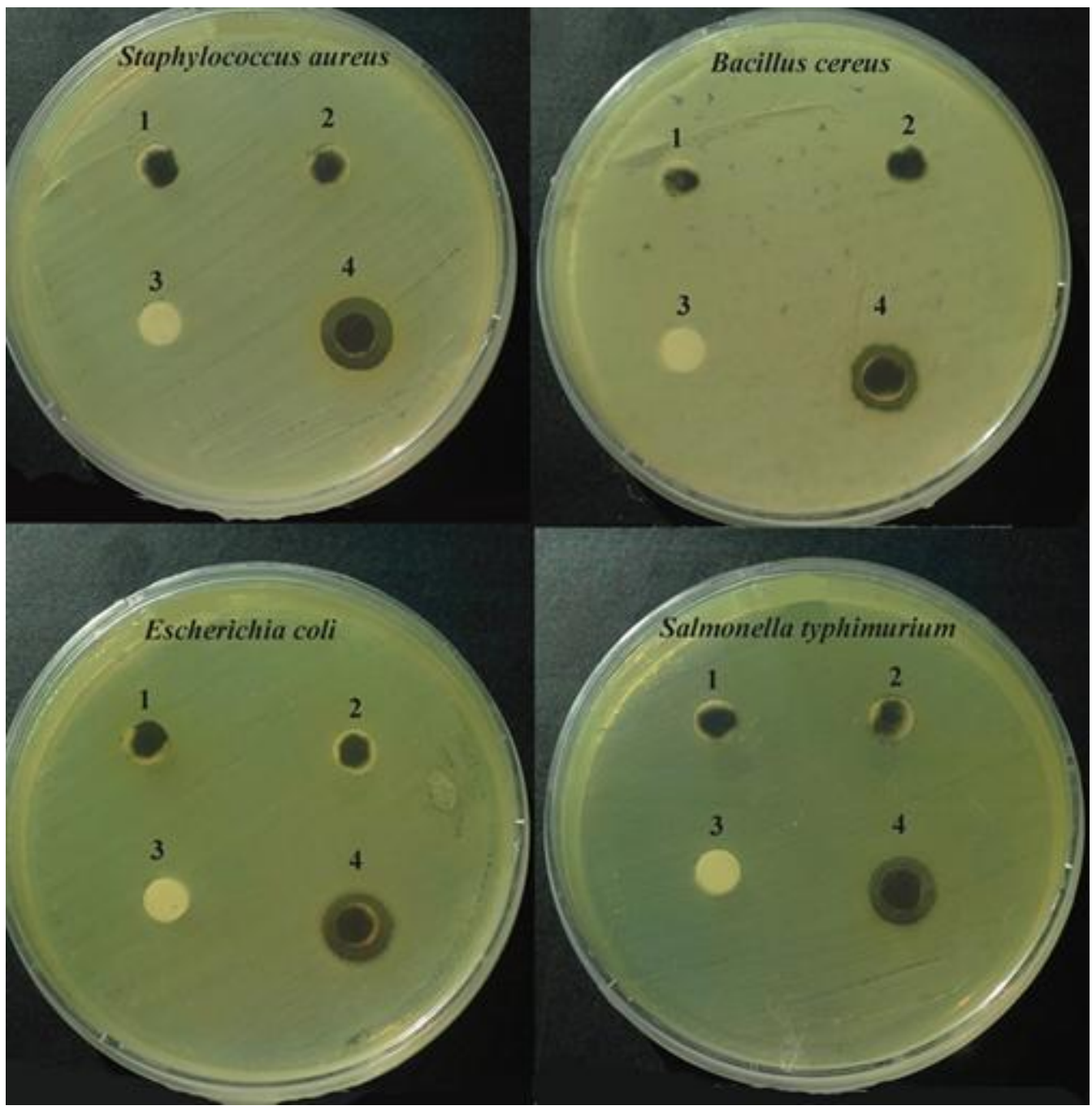



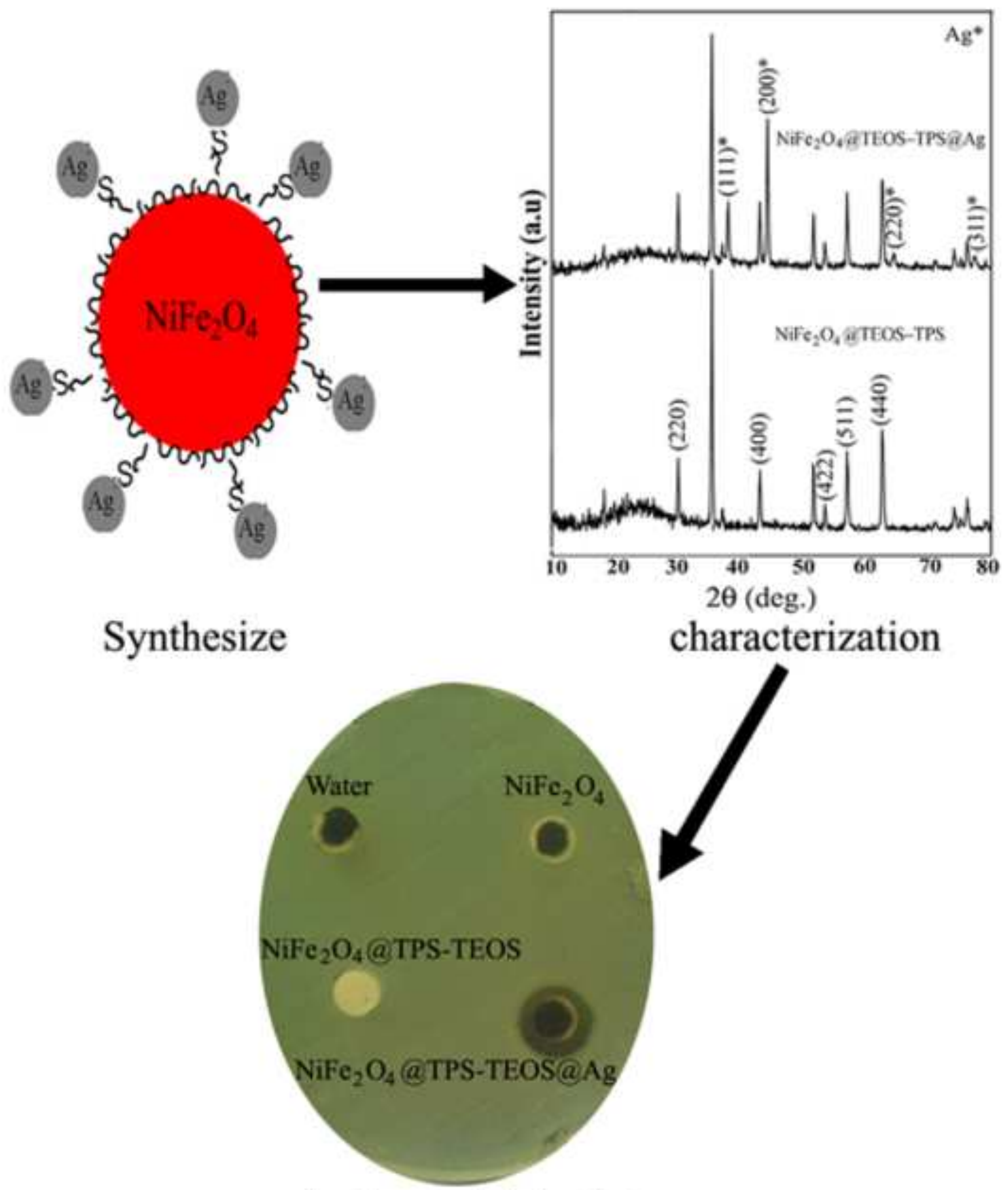

Antibacterial Activity 